\title{
Prevalence and severity of orofacial pain in pregnant women
}

\author{
Prevalência e severidade da dor orofacial em gestantes
}

Fernanda Lopez ROSELL' ${ }^{1}$

Aylton VALSECKI JÚNIOR'

Elaine Pereira da Silva TAGLIAFERRO'

Silvio Rocha Corrêa da SILVA'

\section{ABSTRACT}

Objective

To evaluate the prevalence and severity of oral pain in pregnant women.

\section{Methods}

A cross-sectional study was conducted on a sample of pregnant women who were receiving dental care at a Dental School. A structured questionnaire about self-perception of oral conditions and the presence and severity of orofacial pain in the mouth or teeth in the last 6 months was applied.

\section{Results}

80 pregnant women participated in the study and, of these, 58.8\% reported having a problem with their teeth, 31.3\% periodontal problems, $61.3 \%$ bad taste in mouth and $62.5 \%$ bad breath. Only $22.5 \%$ of pregnant women did not exhibit any form of oral pain. The most frequently reported pains were: pain with hot/cold liquids or sweets (56.2\%) and spontaneous toothache (38.8\%). With regard to severity, mild and moderate pain were the most frequently reported, but there was a group of $23.8 \%$ of pregnant women with severe or very severe pain caused by hot or cold liquids and $18.8 \%$ in the same condition in relation to spontaneous pain.

\section{Conclusion}

The results of this study showed that, despite the high prevalence of pain detected in the pregnant women, severity was low and referred to specific situations.

Indexing terms: Oral health. Pain. Pregnant women.

\section{RESUMO}

\section{Objetivo}

Avaliar a prevalência e a severidade da dor orofacial em gestantes.

\section{Métodos}

O estudo transversal foi realizado em uma amostra de gestantes em atendimento odontológico em uma faculdade de odontologia. Foi aplicado questionário estruturado com perguntas sobre a auto percepção das condições bucais e a presença e a severidade da dor orofacial sentida na boca ou dentes nos últimos 6 meses.

\section{Resultados}

Participaram do estudo 80 gestantes e, destas, 58,8\% afirmaram ter algum problema nos dentes, 31,3\% problema na gengiva, 61,3\% gosto ruim na boca e $62,5 \%$ mau hálito. Apenas $22,5 \%$ não apresentaram nenhum tipo de dor orofacial. As dores mais relatadas foram: dor com líquidos quentes, frios ou doces $(56,2 \%)$ e dor de dente espontânea $(38,8 \%)$. Quanto à severidade, as dores de intensidade leve e moderada foram as mais frequentes, mas havia um grupo de $23,8 \%$ das gestantes com dores intensas ou muito intensas provocadas por líquidos frios ou quentes e 18,8\% na mesma condição em relação à dor espontânea.

\section{Conclusão}

Os resultados do estudo mostraram que, apesar da alta prevalência de dor orofacial encontrada, a severidade foi baixa e relacionada a algumas situações específicas.

Termos de indexação: Saúde bucal. Dor. Gestantes.

\footnotetext{
${ }^{1}$ Universidade Estadual Paulista Júlio de Mesquita Filho, Faculdade de Odontologia, Departamento de Odontologia Social. Rua Humaitá, 1680, Centro, 14801-903, Araraquara, SP, Brasil. Correspondência para / Correspondence to: FL ROSELL. E-mail: <flrosell@foar.unesp.br>.
} 


\section{INTRODUCTION}

Orofacial pain, a condition associated with head, face and neck tissues as well as mouth structures, is one of the most common symptoms of oral health problems. It may have social, economic and psychological consequences for individuals by interfering with behavior, affecting daily activities and changing health perceptions. Moreover it can affect the individual's quality of life' ${ }^{1}$.

It also represents one of the major causes for seeking health services. In the study by Lisboa \& Abbegg ${ }^{2}$ in Canoas (in the Brazilian state of Rio Grande do Sul), $51.3 \%$ of men and $51.5 \%$ of all adults sought dental care only when they had toothache. In the oral health national survey conducted in $2010,27.5 \%$ of adults had had toothache in the previous six months and $15.8 \%$ sought dental care for this reason ${ }^{3}$.

A number of studies have tried to investigate the factors associated with pain, such as demographic, social and cultural ones ${ }^{4-5}$, number of missing teeth due to dental caries $^{6}$ and the pattern of dental appointments ${ }^{7}$.

In adults and elderly residents in the Brazilian capital cities, the prevalence of dental pain was found to be $15.2 \%$ and it was associated mainly with the female gender, blacks or mixed races, those who do not have health insurance, smokers and consumers of soft drinks ${ }^{8}$. Other factors commonly associated with pain are place of residence ${ }^{9}$, alcohol consumption and eating habits ${ }^{4}$. Considering that pain is a subjective symptom, cognitive factors such as knowledge, beliefs and expectations, as well as cultural aspects, have been associated with differences in pain perception ${ }^{10}$.

Pregnancy is a special time in a woman's life, in which health care should be greater. Moreover, she becomes more susceptible to embracing new habits and behaviors. During this period, preventive and educational health programs are important because they can make the mother/woman an information disseminator and help to demystify dental care ${ }^{11}$.

During pregnancy, some care with proper oral hygiene must be taken, but dental treatment, when necessary, is essential, because infections and untreated dental caries can harm the health of the mother and baby. A study conducted with pregnant women in Rio de Janeiro, Brazil, showed a high prevalence of untreated caries, periodontal diseases and orofacial pain ${ }^{12}$. In a study by Hashim $^{13}$, with 800 pregnant women in the Arab Emirates, it was shown that $41.7 \%$ of pregnant women did not use dental services during pregnancy and $32.8 \%$ used them due to dental pain.

Because untreated dental problems can cause orofacial pain, this study evaluated the prevalence and intensity of orofacial pain during the previous six months, in patients who were undergoing treatment in the School of Dentistry of Araraquara, in the Brazilian state of São Paulo.

\section{METHODS}

This cross-sectional, analytical study included pregnant women, aged 18 years and older, who attended the Preventive Dentistry Clinic of the School of Dentistry of Araraquara (UNESP), during 2009-2010. A total of 95 pregnant women were in attendance, but only 80 were included in the study because ten were younger than 18 years and five participated in a pilot study.

The calculation of sample size was not performed because this study used a consecutive sample of all mothers attending the Preventive Dentistry Clinic in the given period (2 years).

Data were collected through a self-applied, structured questionnaire with 18 questions, divided into two parts. In the first part, socioeconomic and demographic variables (age, marital status, years of education, occupation, perception and self-assessed oral health with questions about tooth and gum status) were collected by means of seven questions that have already been used in another study of pregnant women by the same authors ${ }^{14}$.

The second part of the questionnaire collected information about the experience and severity of orofacial pain in the six months before the survey. The pregnant women were asked whether in the last six months they had: "spontaneous toothache; toothache caused by hot/cold liquids or sweets; prolonged burning tongue sensation; pain in the jaw or during chewing; pain when opening the mouth, in the face or around/behind the eyes". The possible answers "yes" or "no" determined the prevalence of orofacial pain. All pregnant women who answered "yes" were also asked about the intensity of pain on a scale of 1 (mild pain) to 4 (very severe). Questions about orofacial pain were adapted from the Nardi study ${ }^{15}$.

Before application, a pre-test was performed with five pregnant women in order to test the appropriateness of the questionnaire. Then a re-test was performed on the same pregnant women after seven days to confirm the 
reproducibility of the instrument by applying the Kappa coefficient in accordance with the criteria of Landis and Koch $^{16}$. The agreement was found to be $88 \%$ with a Kappa value of $0.878(95 \% \mathrm{Cl}, 0.842$ to 0.915$)$.

All the pregnant women received an explanation of the research objectives. The consent form was read by the researcher and signed by the participants before handing out the questionnaire, which was applied in the clinic waiting room before the first appointment. No time limit for completing the questionnaire was set. On average they answered all questions, individually, in 10 minutes. If it was necessary, the researcher clarified the question(s), taking care to avoid influencing the responses.

Data were analyzed using the statistical program Epi Info version 3.5.2. The percentages of women with or without orofacial pain, as well as the severity of the pain, were determined.

All procedures for this research followed the ethical guidelines involving human subjects, approved by Resolution 196/96 of the National Health Council. This study was approved by the Ethics Committee of the School of Dentistry of Araraquara, Univ. Estadual Paulista Júlio de Mesquita Filho (protocol \#36/07).

\section{RESULTS}

A total of 80 pregnant women participated in this study, conducted over a period of two years. They were on average 25 years-old (minimum 18 and maximum 39 years). A total of $32.5 \%$ received eight years of schooling, the maximum being 11 years. Most of them were married $(68.8 \%)$ and $62.5 \%$ were not in employment.

The perception of oral problems showed the following results: the majority (58.8\%) reported having some problem with teeth; however only $31.3 \%$ of pregnant women perceived some problem with gums. When asked what grade they would give to their oral health status, $41.3 \%$ graded excellent/good, $38.8 \%$ regular and $20.1 \%$ poor/very poor. Most of them (61.3\%) reported feeling a bad taste in their mouth and $62.5 \%$ reported bad breath.

Table 1 shows the responses to 8 questions that represented the prevalence of orofacial pain in this study.

Regarding the prevalence of orofacial pain, the results showed that $22.5 \%$ of pregnant women reported no form of orofacial pain, while $77.5 \%$ answered "yes" to at least one of the questions. The severity of reported orofacial pain is shown in Table 2.
Table 1. Prevalence of orofacial pain in pregnant woman from Araraquara (SP)

\begin{tabular}{|c|c|c|c|c|}
\hline \multirow{2}{*}{ In the last six months... } & \multicolumn{2}{|c|}{ Yes } & \multicolumn{2}{|c|}{ No } \\
\hline & $n$ & $\%$ & $n$ & $\%$ \\
\hline 1. Did you feel spontaneous pain (no apparent cause)? & 31 & 38.8 & 49 & 61.2 \\
\hline $\begin{array}{l}\text { 2. Did you feel toothache caused by hot/cold liquids or } \\
\text { candies? }\end{array}$ & 45 & 56.2 & 35 & 43.8 \\
\hline $\begin{array}{l}\text { 3. Did you have a prolonged burning sensation in the } \\
\text { tongue or other parts of the mouth? }\end{array}$ & 6 & 7.5 & 74 & 92.5 \\
\hline 4. Did you feel pain in the joints of the jaw? & 17 & 21.3 & 63 & 78.7 \\
\hline 5. Did you feel pain while chewing? & 14 & 17.5 & 66 & 82.5 \\
\hline 6. Did you feel pain when opening the mouth fully? & 15 & 18.8 & 65 & 81.2 \\
\hline 7. Did you feel pain in the face, in front of the ear? & 19 & 23.8 & 61 & 76.2 \\
\hline 8. Did you feel pain around or behind the eyes? & 11 & 13.7 & 69 & 86.3 \\
\hline
\end{tabular}

Table 2. Severity of orofacial pain (\%) in pregnant women from Araraquara (SP).

\begin{tabular}{|c|c|c|c|c|c|}
\hline \multirow{2}{*}{ Severity } & $\begin{array}{l}\text { Pain- } \\
\text { free }\end{array}$ & Mild & Moderate & Severe & $\begin{array}{l}\text { Very } \\
\text { severe }\end{array}$ \\
\hline & $\%$ & $\%$ & $\%$ & $\%$ & $\%$ \\
\hline 1. Spontaneous toothache & 61.2 & 10.0 & 10.0 & 11.3 & 7.5 \\
\hline $\begin{array}{l}\text { 2. Toothache caused by hot/ } \\
\text { cold liquids or candies }\end{array}$ & 43.8 & 16.2 & 16.2 & 15.0 & 8.8 \\
\hline $\begin{array}{l}\text { 3. Prolonged burning } \\
\text { sensation in the tongue or } \\
\text { other parts of the mouth }\end{array}$ & 92.5 & 3.7 & 2.5 & 1.3 & 0.0 \\
\hline 4. Pain in the joints of the jaw & 78.8 & 13.7 & 2.5 & 3.7 & 1.3 \\
\hline 5. Pain during chewing & 82.4 & 8.8 & 5.0 & 2.5 & 1.3 \\
\hline $\begin{array}{l}\text { 6. Pain when opening the } \\
\text { mouth fully }\end{array}$ & 81.2 & 11.2 & 3.7 & 2.5 & 1.3 \\
\hline $\begin{array}{l}\text { 7. Pain in the face, in front of } \\
\text { the ear }\end{array}$ & 76.2 & 7.5 & 6.3 & 6.3 & 3.7 \\
\hline $\begin{array}{l}\text { 8. Pain around or behind the } \\
\text { eyes }\end{array}$ & 86.2 & 6.3 & 3.7 & 2.5 & 1.3 \\
\hline
\end{tabular}

\section{DISCUSSION}

The pregnant women in this study were, predominantly, young (average age of 25 years). On average they had nine years of schooling, which would correspond to full secondary education. However, this does not correspond to reality, because not all students finish elementary school in a period of eight years. No pregnant women attended undergraduate courses, because they studied 11 years at most. Most respondents (62.5\%) did not work and $68.8 \%$ were married. Demographic data are important to characterize the sample, because life and work conditions affect the way in which individuals think and feel. In this study, pregnant women are young, with some schooling but without employment.

As regards the perception of oral health, the pregnant women had a positive assessment. Amongst them, $41.3 \%$ graded their oral health as excellent or good and $38.8 \%$ as moderate, similar to the results found by Silva et al. ${ }^{14}$ who had previously studied pregnant women in the same Clinic. A total of $58.8 \%$ reported having trouble 
with their teeth and $31.3 \%$ reported having problems with the gums. These values are similar to others, particularly in relation to perception of gingival/periodontal problems. Silva et al. ${ }^{17}$ found that $31 \%$ of adults perceived themselves as having gum problems. It was also observed that the majority perceived a bad taste in the mouth (61.3\%) and bad breath $(62.5 \%)$. Honkala \& Al-Ansari18 found that a third of pregnant women from Kuwait believed they had periodontal problems and all of them graded their oral health as poor.

Considering that, in this study, no clinical examination was performed, it is impossible to compare our results with the clinical status of the women examined. However, studies on self-perception of oral health 17,19 have shown that most people grade their oral health better than it really is, because their evaluation takes into account subjective factors that are not measured by the professional. Thus it is very important to understand the factors people take into consideration when making their assessments, because their behavior and the search for health services will depend on this perception.

As for the negative impact of oral health on quality of life, Locker \& Grushka ${ }^{20}$ says that it is possible to find people with chronic problems who report higher levels of quality of life than healthy individuals, and one possible explanation for this is the subjective and multidimensional characteristic of this concept. For Jokovic \& Locker $^{19}$ the often asymptomatic nature of oral diseases, as well as fear, anxiety or even aversion to dental treatment, can be a decisive factor in their behavior.

The results on the prevalence of orofacial pain varied according to the area covered by the questionnaire. The main pain experienced by pregnant women was that caused by hot/cold liquids or sweets ( $56.3 \%)$, followed by spontaneous pain $(38.8 \%)$, pain in the face $(23.8 \%)$ and pain in the joints of the jaw (21.3\%).

Nardi ${ }^{15}$ applied the same questionnaire to workers from southern Brazil and found similar values, especially in the following areas: pain caused by hot/cold liquids $(49.1 \%)$ and pain in the joints of the jaw (20.2\%). Locker \& Grushka ${ }^{20}$ also found $28.8 \%$ of pain caused by hot or cold liquids and spontaneous pain in $14.1 \%$ of adults from Canada.

According to Oliveira \& Nadanovsky ${ }^{12}$ the most frequent pain in pregnant women are headaches, pelvic pain and orofacial pain. All of them significantly affect activities of daily life and must be investigated. In a study conducted by the authors amongst 504 pregnant women from Rio de Janeiro, pain was a major problem for this group, with a negative effect on their quality of life.
With regard to the severity of orofacial pain in pregnant women, the most frequent pain was that of mild and moderate intensity, which is in line with other studies ${ }^{20-21}$. However it can be seen that some women had severe or very severe pain in all areas. For example, $23.8 \%$ of pregnant women reported pain caused by hot or cold liquids and $18.8 \%$ with spontaneous toothache. One can see that the most common pain (spontaneous toothache and pain caused by liquids) is related to dental problems, indicating that caries may be more prevalent than periodontal pain or pain in the joints of the jaw. These problems can be solved by means of prevention programs and access to treatment.

Another explanation for the high prevalence of pain related to dental problems may be the fact that other types, such as pain in the face, pain while chewing or in the joints of the jaw, have to be severe before the individuals actually notice.

For Gomes \& Abegg 22 , toothache and function limitation are more strongly associated with the impact on daily performance than the presence of disease. This type of pain causes concern because it generates suffering and it does not require demand for health services, as stated by Lacerda et al. ${ }^{23}$.

Lacerda et al. ${ }^{24}$ stated that the impact of oral health on daily performance depends on social, behavioral and cultural aspects. According to the authors, increased access to information is related to raised awareness of the importance of having good health and greater adherence to preventive measures and self-care. Thus, there is a clearer perception of the problems.

It is likely that the suffering and limitations experienced by individuals are more reliable characteristics of their oral health status than the biological after-effects of injuries and events measured by most clinical indicators. Therefore the use of subjective indicators is recommended in defining actions and priority groups in the health services.

\section{CONCLUSION}

Despite the high prevalence of orofacial pain, severity was low and limited to specific situations, in the studied sample.

\section{Collaborators}

FL ROSELL participated in the study design, data collection and writing the paper. JR VALSECKI collaborated in interpreting the results and writing the paper. EPS TAGLIAFERRO collaborated in the writing of the paper. SRC SILVA participated in the conception, study design and writing the paper. 


\section{REFERENCES}

1. Steele JG, Walls AWG, Ayatollahi SMT, Murray JJ. Major clinical findings from a dental survey of elderly people in three different English communities. Br Dent J. 996;180(1):7-23.

2. Lisboa IC, Abegg C. Hábitos de higiene bucal e uso de serviços odontológicos por adolescentes e adultos do Município de Canoas, Estado do Rio Grande do Sul, Brasil. Epidemiol Serv Saúde. 2006;15(4):29-39. doi: 10.5123/S167949742006000400004.

3. Brasil. Ministério da Saúde. Secretaria de Atenção à Saúde. Departamento de Atenção Básica. Coordenação de Atenção Básica. SB Brasil 2010: pesquisa nacional de saúde bucal. Brasília: Ministério da Saúde; 2004

4. Bastos JL, Gigante DP, Peres KG. Toothache prevalence and associated factors: a population based study in southern Brazil. Oral Dis. 2008;14(4):320-6. doi: 10.1111/j.16010825.2007.01379.x.

5. Pau AK, Croucher R, Marcenes W. Prevalence estimates and associated factors for dental pain: a review. Oral Health Prev Dent. 2003;1(3):209-20.

6. Lacerda JT, Simionato EM, Peres KG, Peres MA, Traebert J, Marcenes W. Dental pain as the reason for visiting a dentist in a Brazilian adult population. Rev Saúde Pública. 2004;38(3):4538. doi: 10.1590/S0034-89102004000300017.

7. Alexandre GC, Nadanovsky P, Lopes CS, Faerstein E. Prevalência e fatores associados à ocorrência da dor de dente que impediu a realização de tarefas habituais em uma população de funcionários públicos no Rio de Janeiro, Brasil. Cad Saúde Pública. 2006;22(5):1073-8. doi: 10.1590/S0102$311 \times 2006000500020$

8. Peres MA, Iser BPM, Peres KG, Malta DC, Antunes JLF. Desigualdades contextuais e individuais da prevalência de dor dentária em adultos e idosos no Brasil. Cad Saúde Pública. 2012;28(Supl. 0):S114-23. doi: 10.1590/S0102311X2012001300012.

9. Peres MA, Peres KG, Frias AC, Antunes JL. Contextual and individual assessment of dental pain period prevalence in adolescents: a multilevel approach. BMC Oral Health. 2010;10:20

10. Slade GD. Epidemiology of dental pain and dental caries among children and adolescents. Community Dent Health. 2001;18(4):219-27

11. Costa ICC, Marcelino G, Berti Guimarães M, Saliba NA. A gestante como agente multiplicador de saúde. RPG Rev PósGrad. 1998;5(2):87-92

12. Oliveira BH, Nadanovsky P. The impact of oral pain on quality of life during pregnancy in low-income Brazilian women. J Orofac Pain. 2006;20(4):297-305

13. Hashim R. Self-reported oral health, oral hygiene habits and dental service utilization among pregnant women in United Arab Emirates. Int J Dent Hyg. 2012;10(2):142-6. doi: 10.1111/j.1601-5037.2011.00531.x.
14. Silva SRC, Rosell FL, Valsecki Júnior. Percepção das condições de saúde bucal por gestantes atendidas em uma unidade de saúde no município de Araraquara, São Paulo, Brasil. Rev Bras Saúde Matern Infant. 2006;6(4):405-10.

15. Nardi A. Dor orofacial, absenteísmo e qualidade de vida em trabalhadores do sul do Brasil [dissertação]. Joaçaba: Universidade do Oeste de Santa Catarina; 2008.

16. Landis JR, Koch GG. The measurement of observer agreement for categorical data. Biometrics. 1977;33(1):159-74.

17. Silva SRC, Castellanos Fernandes RA. Self-perception of oral health status by the elderly. Rev Saude Pública. 2001;35(4):34955. doi: 10.1590/\$0034-89102001000400003

18. Honkala S, Al-Ansari J. Self-reported oral health, oral hygiene habits, and dental attendance of pregnant women in Kuwait. J Clin Periodontol. 2005;32(7):809-14. doi: 10.1111/j.1600051X.2005.00770.x.

19. Jokovic A, Locker D. Dissatisfaction with oral health status in an older adult population. J Public Health Dent. 1997;57(1):40-7.

20. Locker D, Grushka M. Prevalence of oral and facial pain and discomfort: preliminary results of a mail survey. Community Dent Oral Epidemiol. 1987;15(3):169-72.

21. Wandera MN, Engebrestsen IM, Rwenyonyi $\mathrm{CH}$, Tumwine J, Anstrom AN. Periodontal status, tooth loss and self-reported periodontal problems effects on oral impacts on daily performances, OIDP, in pregnant women in Uganda: a crosssectional study. Health Qual Life Outcomes. 2009:7:89. doi: 10.1186/1477-7525-7-89

22. Gomes AS, Abegg C. O impacto odontológico no desempenho diário dos trabalhadores do Departamento Municipal de Limpeza Urbana de Porto Alegre, Rio Grande do Sul, Brasil. Cad Saúde Pública. 2007:23(7):1707-14. doi: 10.1590/S0102$311 \times 2007000700023$

23. Lacerda JT, Ribeiro JD, Ribeiro DM, Traebert J. Prevalência da dor orofacial e seu impacto no desempenho diário em trabalhadores das indústrias têxteis do município de Laguna, SC. Ciênc Saude Coletiva. 2011;16(10):4275-82. doi: 10.1590/S141381232011001100033

24. Lacerda JT, Castilho EA, Calvo MCM, Freitas SFT. Saúde bucal e o desempenho diário de adultos em Chapecó, Santa Catarina, Brasil. Cad Saúde Pública. 2008:24(8):1846-58. doi: 10.1590/ S0102-311X2008000800013.

Received on: 20/9/2012 Final version resubmitted on: 24/5/2013 Approved on: 18/9/2013 
